\title{
Veterans (Librarians) Helping Veterans
}

\author{
Tom Adamich
}

ibraries serving veterans and veterans' needs is not a new concept. More than 120,000 libraries across the United States support veterans by providing "safe places where people care and want to help, and where core professional values of respect and confidentiality are upheld." ${ }^{\prime}$ This role defines not only the inherent service mission of libraries in general, but also the democratic and inclusive qualities that library workers strive to uphold daily.

\section{Library Support for the Veteran and Military Communities}

There have been a number of recent efforts by library workers to provide spaces, services, collections, and programming specifically aimed at patrons from the veteran and military communities. Roy et al. found that "libraries of all sizes and locations offer services tailored for patrons who are veterans and their family members." ${ }^{2}$ Many of these initiatives originate at the individual library level. The High Springs Branch Library of the Alachua County Library District, for example, partnered with the veteran service organization Help Heal Veterans to host a therapeutic craft kit program for local veterans. ${ }^{3}$ Another example is the University of Utah, where library workers developed displays of student veterans in the library in order to "inform and educate the campus about the experience of their veteran classmates."

Although many libraries have been supporting the veteran and military communities at the local level, there are limitations to this approach. Library workers interested in developing programs and services for the veteran and military communities may have to develop their approach from scratch. Members of the veteran and military communities are also likely to find that availability of programming or services may be uneven from one library to another. Fortunately, there are recent initiatives to provide services, and establish guidelines and best practices, for serving veterans at the state or national level. The Library of Congress's Veteran History Project, for example, engages libraries, educators, and other stakeholders at the national level to collect and submit veteran oral histories for preservation and research. ${ }^{5}$ Another national initiative is the Institute for Museum and Library Services' (IMLS) Community Salute project, which developed a series of white papers aimed at developing and sharing best practices for libraries interested in working with the veteran and military communities. ${ }^{6}$

\section{Veterans Connect @ the Library}

One major effort toward

engaging veteran and military communities in libraries can be found in

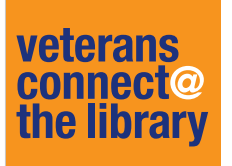
connect the library veterans

connect@ the fibrary the State of California, where IMLS funds Veterans Connect @ the Library. The project is administered by the State Library, and the California Department of Veterans Affairs (CalVet) is the chief partner. The project's purpose is to make sure that 1.8 million veterans in California, the highest in the country, receive their benefits. It is estimated that only approximately 20 percent of veterans utilize their benefits, and libraries' roles as service centers within the community put them in an ideal position to help connect veterans with those resources. There are currently fifty-seven Veteran Resource Centers in public libraries in California, and there have been more than 30,000 interactions with veterans and their family members.

Libraries and volunteers work in partnership with CalVet, County Veteran Service Offices, and local veteran service organizations. The project mission is to make veterans aware of vital resources and to send them to agencies that can help them claim and better utilize the benefits to which they are entitled. Library Veteran Resource Centers are staffed by trained volunteers, often veterans themselves. In addition to providing information about benefits, these libraries provide usual patron 
services, including assisting veterans on their resumes and job applications, helping them set up and access email and providing guidance with research on health, housing, education, and employment.

Veterans are served locally, and libraries are actively engaged in their communities. Library workers participate in regional stand downs for homeless veterans (http://nchv.org/index.php /service/service/stand_down/), coordinate or assist at veteran job fairs, and are active on local community veteran councils. Libraries also create and deliver well-attended programs specific to veterans, including job-search and résumé-writing workshops, book and film clubs, computer-skills classes, financial literacy for veterans, and veteran panel presentations.

The Veterans Connect @ the Library website (https:// calibrariesforveterans.org/index.html) features resources that include the online edition of Federal Benefits for Veterans, Dependents, and Survivors, the California Veterans Resource Book, a map of CalVet liaisons in California, as well as other important guides, forms, and links.?

\section{The ALA Veteran Caucus Membership Initiative Group (MIG)}

Although initiatives such as IMLS's Community Salute and Veterans Connect @ the Library have furthered discussions of how to best serve the veteran and military communities, ALA does not currently offer a space dedicated to this conversation. Accordingly, a group of library workers led by Sarah LeMire, an Army veteran and librarian at Texas A\&M University, initiated a petition in July 2018 to create a Veteran Caucus Membership Initiative Group.

The Veteran Caucus, according to its Statement of Purpose, is intended to be "an Association-wide, national initiative built by a network of veteran- and military-affiliated library workers, trustees, supporters, and partners from government, private industry, academia, and civil society." ${ }^{8}$ The library workers behind the Veteran Caucus petition envision the organization as a space for library workers from all types of libraries to discuss their efforts toward serving veterans and military communities. One goal of the Veteran Caucus, for instance, is to develop a cultural competency toolkit for working with the veteran and military communities. This toolkit will help library workers "identify potential pitfalls when working with the veteran and military communities and also share best practices for effective outreach, programming, and policies."

In addition to supporting library workers who work with the veteran and military communities, the Veteran Caucus aims to support and recruit library workers who are veterans and members of military communities. Veterans often feel an affinity toward other former service members, and many veterans miss the camaraderie they experienced in the military. Although there is little information about the number of veterans who work in libraries, the Veteran Caucus intends to create a space for library workers who are veterans, allowing them to find each other and develop their own community. The Veteran Caucus will also to encourage library workers who are veterans to further support their military communities through their libraries. This is a personal ethos for the Veteran Caucus leadership team, several of whom are veterans themselves. Many also have other ties to military communities.

\section{Military Veterans as Library Workers- GODORT Member Profile}

Veteran Caucus anticipates finding members from virtually every ALA division and round table, but one group that may include a disproportionate number of library workers who are veterans, or who serve veterans, is GODORT. In its mission to serve government information needs, ALA GODORT mem-

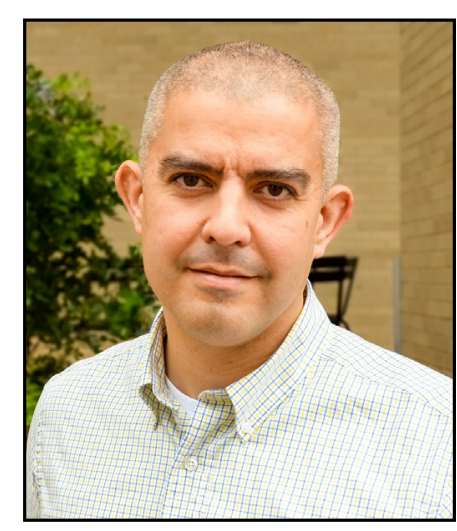
bers, including those members who administer and contribute as FDLP coordinators have been frequent and natural partners in providing veterans with information, particularly information created and produced by the US Department of Veterans Affairs. ALA GODORT members are also experienced in connecting veterans with federal agency resources and services, which may include the US Office of Personnel Management, Department of Homeland Security, and the Office of Management and Budget. GODORT has experience supporting the development of early career librarians by participating in the ALA Emerging Leaders program since 2015. This background in professional support provides great potential for GODORT to serve as a key partner in the Veteran Caucus. It is in that spirit that GODORT member, and veteran-as-librarian, Sean Buckner is profiled in this article. His experience reflects the benefits of encouraging veterans to join the government information profession.

\section{Please tell us about yourself.}

My name is Sean Buckner and I am the digital preservation librarian at Texas A\&M University. I came to Texas A\&M over three years ago from the University of Utah where I worked as the digital preservation systems coordinator for two years. I received my MS in Information from the University 
of Michigan in 2012. I also hold BA and MA degrees in Linguistics from Brigham Young University and the University of Utah respectively. Additionally, I hold a TESOL Certificate (Teaching English to Speakers of Other Languages) and I taught English in Chile for a number of years. I am fluent in Spanish and have studied languages such as Arabic, Japanese, German, Pashto, and Italian. I am a father of four and we all share some Latin American background.

\section{Please tell us about your military career.}

I joined the Army in my early thirties and have served for over sixteen years in the Army National Guard. The entirety of my career I have worked in military intelligence, primarily as an Arabic or Spanish linguist. In 2008, I deployed to Afghanistan where I served for a year. My father, wife, and brother all served in the Army, while another brother, a brother-in-law, and my son currently serve in the Air Force.

\section{Please tell us about your library education and career to date.}

As I stated earlier, I received my librarian degree in 2012 and was very fortunate to be able, upon graduation, to immediately begin working in the area of my choice, digital preservation. After two years working at the J. Willard Marriott Library at the University of Utah helping to implement the Ex Libris Rosetta digital preservation system and develop interoperable workflows with other content management systems, ${ }^{10}$ I was happy to accept a faculty position (trailing my wife, a fellow librarian and veteran herself) at the Texas A\&M University Libraries. Becoming a Digital Preservation Librarian was a dream job for me and at A\&M I was given the charge of developing a digital preservation program for the Libraries. I now work with Archivematica, DuraCloud, and the Digital Preservation Network (DPN), while managing content on numerous local server spaces, in order to preserve the Libraries's sizeable digital collections.

\section{How has your role as an armed services professional contributed to your work as a librarian?}

Believe it or not, I see my military and library occupations as similar in many ways. "Intelligence" is simply a military term for "information," and in either position, it has been my job to gather or process information and make it available to those who need it. Granted, my military role isn't one of preservation per se, nor does my library role come with as many inherent dangers, inconveniences, or severe outcomes, but the core task is one of managing data and providing accurate information, mostly in digital form. Attributes and skills that I have gained from my military service that contribute to my success as a librarian include attention to detail, accuracy, and thoroughness; leadership, collaboration, and interpersonal skills; as well as reliability, responsiveness, and perspective. I am also appreciative of my supervisor and library administrators who are patient and supportive of my continued service, understanding that I have to deal with demands and time commitments from the Army that have occasionally taken me away from my work and family for days, weeks, or even months at a time.

\section{Describe your experience as an ALA Emerging Leader.}

I was honored to be accepted as a 2016 Emerging Leader (EL), and further honored to be sponsored financially by GODORT for that year. The EL program brings early career library professionals together to develop collaborative skills by working in small groups on a project proposed by any one of ALA's various organizations. I was glad to be chosen to work on a project submitted by the International Relations Round Table (IRRT) that had major preservation considerations. Over the course of six months or so, my fellow team members and I developed web content on disaster planning for libraries around the world, ${ }^{11}$ which we also shared in a poster presented at the 2016 ALA Annual Conference. ${ }^{12}$ The EL program additionally attempts to provide participants with subsequent opportunities for committee work within ALA while endorsing equity, diversity, and inclusion (EDI) throughout the library profession. I am grateful to GODORT for selecting and sponsoring me, and I have been a member ever since.

\section{How has the ALA Emerging Leaders Program contributed to your success as a librarian?}

I'd say my greatest take-away from the EL program was a novice understanding of how important EDI is to the library field. I learned a lot from my EL experience, but a piqued interest in EDI issues has had the greatest effect on my nascent career. I followed up my EL experience by attending the Minnesota Institute for Early Career Librarians (MIECL) from Traditionally Underrepresented Groups. Like EL, MIECL is a selective process and I was fortunate to be accepted. My participation in MIECL gave me an even deeper understanding of the need for EDI and a greater appreciation for the intrinsic value and strength of EDI in the field.

\section{Describe your experiences as an ALA GODORT member.}

As a GODORT member, for two years I served on the Rare and Endangered Government Publications (REGP) Committee, 
which also has strong preservation considerations. I've also attended GODORT presentations and sessions at the ALA Annual Conference and have followed topics of interest on listserv threads. But I haven't had a larger role within the Round Table as the majority of my ALA service has been in the Preservation and Reformatting Section (PARS) of ALCTS.

\section{How has your membership in GODORT contributed} to your success as a librarian?

What I have gleaned from my GODORT service and exposure, I have eagerly applied in working on our library's Government Documents Digitization Initiative (GDDI), where I've had a small but key role in the workflow to digitize our government documents, save and preserve the digital files, and make them accessible online as part of the HathiTrust US Federal Government Documents Program. Also, GODORT has given me opportunities to serve and learn in areas outside of day-to-day digital preservation duties, which I believe has helped me to become a more well-rounded and better-informed librarian.

\section{What, in your opinion, is the greatest need for veterans that libraries can help satisfy?}

Well, LeMire and Mulvihill literally wrote the book on that, so I'd say read it (Serving Those Who Served, Librarian's Guide to Working with Veteran and Military Communities). ${ }^{13}$ But I'll add a couple of cents' worth of my opinion and say that veterans are as diverse as the general population and have information needs similar to those of other library patrons. In that sense, veterans are looking for similar information and resources as the next individual; however, the military experience is often transformative and veterans may perceive and internalize things differently from other patrons and may locate and utilize resources in different manners. In essence, library professionals can best help satisfy veterans' needs by learning to communicate effectively with veterans and by accommodating the way in which they locate and utilize resources within the library space.

\section{You are aware of the development of the ALA} Veteran Caucus Membership Initiative Group; how do you see this group benefitting veterans and ALA members who are veterans?

I'm excited for the Veteran Caucus. Having served in the military is a defining experience and it creates an affinity or a sort of kinship that many veterans want to share. There are few veterans among the librarian ranks and I know a very few, but I have yet to meet another librarian who is currently serving. I've heard there may be a few out there and I'd like to network with them. I'd also like to work toward developing best practices for serving patrons who are veterans, as well as exploring how librarianship might be a more appealing career opportunity for those who have served. I'd also like to look into studying how current library and/or archival best practices might help to address the military community's information needs. ${ }^{14}$

\section{Concluding Thoughts}

Supporting military veterans like Sean Buckner to become librarians, and providing veterans services resources to libraries, are just a few of the benefits of creating the Veteran Caucus. As ALA's government information support group, GODORT will be a great partner for the Veteran Caucus as it grows and develops into an important veteran resource and advocacy group.

\section{Acknowledgements}

Information about Veterans Connect @ the Library was provided by Karen Bosch Cobb and Jacquie Brinkley, co-managers of the Veterans Connect @ the Library, which is an IMLS grant-funded project administered in California by the California State Librarian.

\section{References}

1. American Library Association, "Libraries Help and Honor our Veterans," November 2016, http://www.ala .org/news/sites/ala.org.news/files/content/ALA-Veterans -2016Nov10.pdf .

2. Loriene Roy et al., "Public Library Services for Veterans: Selected Brief Case Studies," Public Library Quarterly 35, no. 3 (2016): 222-42, https://doi.org/10.1080/01616846 .2016 .1210452 .

3. Alicia A. Antone and Patricia E. Carr, "The Alachua County Library District's 'Heal Vets Craft Program' Celebrates Veterans," Florida Libraries 60, no. 2 (2017): 6-9.

4. Lorelei Rutledge and Sarah LeMire, "Beyond Disciplines: Providing Outreach to Underserved Groups by Demographic," Public Services Quarterly 12 no. 2 (2016): 11324, https://doi.org/10.1080/15228959.2016.1157565.

5. "Veterans History Project," Library of Congress, accessed July 28, 2018, http://www.loc.gov/vets/.

6. "Community Salute," Institute of Museum and Library Services, accessed July 28, 2018, https://www.imls.gov /issues/national-initiatives/community-salute.

7. "Veterans Connect @ the Library," California State Library [California Libraries for Veterans], accessed July 20, 2018, https://calibrariesforveterans.org/index.html.

8. Sarah LeMire and Daniel Snedden, "ALA Veteran Caucus Membership Initiative Group," Veteran Caucus 
Statement of Purpose (working paper, ALA Connect, 2018), https://connect.ala.org/communities/community -home/librarydocuments/viewdocument?DocumentKey $=e d 84 c 4 d b-7 b 63-4 f a a-9 a d c-0448117 d 557 e$.

9. LeMire and Snedden, "ALA Veteran Caucus Membership Initiative Group."

10. Anna Neatrour et al., "The SIMP Tool: Facilitating Digital Library, Metadata, and Preservation Workflow at the University of Utah's J. Willard Marriott Library," D-Lib Magazine 20, no. 7/8 (2014), https://doi.org/10.1045 /july2014-neatrour.

11. Phil Morehart, "Emerging Leaders 2016: Meet the New Class," American Libraries 47 no. 3/4 (March/April 2016), https://americanlibrariesmagazine.org/2016/03/01 /emerging-leaders-2016/.

12. Jason Broughton et al., "Disaster Planning and Recovery," IRRT Free Links, Accessed August 4, 2018, https:// sites.google.com/site/irrtfreelinks/disaster-planning -and-recovery.

13. Sarah LeMire and Kristin Mulvihill, Serving Those Who Served: Librarian's Guide to Working with Veteran and Military Communities (Santa Barbara, CA: Libraries Unlimited, 2017).

14. Sean Buckner, email message to author Tom Adamich, July 19, 2018. 